\title{
Influence of Certain Herbicides on some Peanut Characteristics
}

\author{
Lila. A. Reda ${ }^{1}$; A.M. A. Mostafa ${ }^{{ }^{*}}$; Y. M Ahmed ${ }^{1}$; A. M. El-Adawy ${ }^{2}$ and A. M. Khozimy ${ }^{1}$ \\ ${ }^{1}$ Department of Plant Protection, Faculty of Agriculture, Suez Canal University, Ismailia-41522, Egypt \\ ${ }^{2}$ Plant Protection Institute, Agricultural Research Center, Dokki, Giza, Egypt
}

Received: $2 / 9 / 2018$

\begin{abstract}
The side effect of four herbicides, pendimethalin, oxyfluorfen fluazifop $-\mathrm{P}-$ butyl and clethodim on certain peanut characteristics such as chlorophyll dry weight of each of plants and pods, oil and protein contents of the seeds were estimated. The herbicides at complete recommended and at half rates with or without KZ oil were applied. The results clearly showed that the highest increase in chlorophyll ( $\mathrm{a}, \mathrm{b}$ and total) was obtained with the treatment of clethodim at half rate $+1500 \mathrm{ml}$ oil; whereas the treatment of clethodim at half rate without oil recorded the lowest effect during 2004 and 2005 seasons. The results also revealed that the highest effect on dry weigh of each of plants and pods was more pronounced for the treatment of the half rate of clethodim plus $1500 \mathrm{ml}$ of mineral oil. The herbicides had no effect on each of oil and crude protein content of peanut seeds.
\end{abstract}

Keywords: Herbicides, characteristics, influence, peanut

\section{INTRODUCTION}

Peanut or groundnut (Arachis hypoagea L.) is an excellent source of oil and protein. The invasion of weeds resulted in great losses in both yield and quality. Chemical control of peanut weeds is considered an excellent alternative method to the manual control. The herbicides may be applied as pre - emergence (Silva et al., 1983; Deer et al., 1985; Colvin et al., 1985) or postemergence treatments (Rogers et al., 1980; Ennis and Ashley, 1988; Fletcher and Kirwood, 1982). Preemergence treatment of herbicides may allow weeds to emerge after certain period of time. However, application of pre - or - post emergence herbicides delays the emergence of weeds. Mineral oil can be added to herbicides for melioration weeds control (kudsk, 1984; Glemmestad, 1985; Barrol, 1989). Chemical control treatments can affect peanut growth and yields (Grichar and Boswell, 1986).

The main subjective of this research is to shed light on the the effect of some herbicides on certain peanut characteristic such as chlorophyll, dry weight of each of plants and pods, oil and protein contents of peanut seeds.

\section{MATERIALS AND METHODS}

\section{Chemical used:}

Pendimethalin 12\% EC (Stomp)

IUPAC name: $\mathrm{N}$ - (1- ethylpropyl) - 2, 6 - dinitro-3, 4xylidine

Oxyfluorfen 12\% EC (Goal)

IUPAC name: 2-a, a, a trifluoro - p- tolyl 3- emoxy-4nitro phenyl ether

Fluazifop-P-butyl 12\% EC (Fusilade super)

IUPAC name: 2 - [4 - (5 - trifluoro methyl)]

Clethodim 12\% EC (Select super)

IUPAC name: $( \pm)$ - 2 - [(E) - 3 - chloro allyloxy imino propyl 5 - [2 - (ethyl thio) propyl] hydroxyl - cyclohex - 2- enone

\section{Field experiment:}

The experiment was carried out at Ismailia Agricultural Research Station, Agricultural Research
Centre (ARC), throughout the two successive seasons, 2004 and 2005. Peanut seeds CV. (Giza 16) were sown on 15-4 - 2004 and on $18-5-2005$ at a constant rate of $40 \mathrm{Kg}$. pods/fed. The cultivated area was divided into 52 plots. Each plot was prepared as ridges (6 ridges), 60 $\mathrm{Cm}$. between each other. The distance between the planted pods was $10 \mathrm{Cm}$. on one side of the ridge. Normal agricultural practices, irrigation and fertilization were followed. The experiment included 12 treatments:

1 - Pendimethalin $12 \%$ EC (Stomp) at the rate of $850.0 \mathrm{~g}$. (a.i.)/fed.

2 - Pendimethalin 12\% EC (Stomp) at the rate of $425.0 \mathrm{~g}$. (a.i.)/fed.

3 - Oxyfluorfen $12 \%$ EC (Goal) at the rate of $180.0 \mathrm{~g}$. (a.i.)/fed.

4 - Oxyfluorfen 12\% EC (Goal) at the rate of $90.0 \mathrm{~g}$. (a.i.)/fed.

The two herbicides were applied to the soil surface after sowing but before irrigation (preemergence).

5- Fluazifop - P- butyl 12.5\% EC (Fusilade super) at the rate of $187.5 \mathrm{~g}$. (a.i.)/fed.

6- Fluazifop - P - butyl 12.5\% EC (Fusilade super) at the rate of 93.75 g. (a.i.)/fed

7- Fluazifop - p - butyl 12.5\% EC (Fusilade super) at the rate of $93.75 \mathrm{~g}$. (a.i.)/fed. Mixed with (KZ oil) at the rate of $1000 \mathrm{ml} / \mathrm{fed}$.

8- Fluazifop -P - butyl 12.5\% EC (Fusilade super) at the rate of 93.75 g. (a.i.)/ fed. Mixed with (KZ oil) at the rate of $1500 \mathrm{ml} / \mathrm{fed}$.

9- Clethodim $12.5 \%$ EC (Select super) at the rate of 125.0 g. (a.i.)/fed.

10- Clethodim $12.5 \%$ EC (Select super) at the rate of 26.5 g. (a.i.)/fed.

11- Clethodim $12.5 \%$ EC (Select super) at the rate of 26.5 g. (a.i.)/fed. mixed with (KZ oil) at the rate of $1000 \mathrm{ml} / \mathrm{fed}$.

12- Clethodim $12.5 \%$ EC (Select super) at the rate of 26.5 g. (a.i.)/fed. mixed with (KZ oil) at the rate of $1500 \mathrm{ml} / \mathrm{fed}$. 
The herbicides were applied at post - emergence stage as foliar spraying, 30 days after sowing, by the aid of a knapsack sprayer, at a volume rate $200 \mathrm{~L} /$ fed. The experiment was designed as complete randomized blocks. Each treatment was represented by four plots as replicates. Four plots were served as control.

Determination of chlorophyll ( $a, b$ and total) in peanut plants:

To determine the photosynthetic pigments chlorophyll ( $\mathrm{a}, \mathrm{b}$ and total), leaves were collected, 75 days after sowing. Samples were put in $10 \mathrm{ml}$ of $85 \%$ acetone in dark bottle, and left to stand for 15 hours at room temperature, then the samples were filtered in glass wool into $50 \mathrm{ml}$ volumetric flask and made up to $50 \mathrm{ml}$ with $85 \%$ acetone solution. The optical density of the samples were measured at wavelength of 662, 664 and $440.5 \mathrm{~nm}$ using Beckman DK-2 Spectrophotometer. Concentrations of chlorophyll ( $a$ and b) and carotenoides were calculated as follows:

$$
\begin{aligned}
\text { Chlorophyll } \mathrm{a}= & (9.784 \times \mathrm{E} 662)-(0.99 \times \mathrm{E} 662)= \\
& \mathrm{mg} / \mathrm{g}(\mathrm{D} . \mathrm{Wt}) \\
\text { Chlorophyll } \mathrm{b}= & (21.426 \times \mathrm{E} 644)-(0.99 \times \mathrm{E} 644)= \\
& \mathrm{mg} / \mathrm{g}(\mathrm{D} . \mathrm{Wt})
\end{aligned}
$$

$\mathrm{E}=$ optical density at wavelength indicated (Wettstein, 1957; Fadl and Sari El-Deen, 1978)

Determination of dry weight of each of peanut plants and pods:

From each experiment plots, five peanut plants were randomly collected at 45, 75 and 105 days after sowing. The plants - include pods -were left four days in the laboratory and then were dried for four days, under $70^{\circ} \mathrm{C}$ in oven. The dried plants and pods were weighted and recorded.

The increasing percentage in dry weight was calculated using the following equation: -

$\%$ increasing in dry weight $=$ $\frac{\text { D.W as g/plant in treatment }- \text { D.W as g/plant in check }}{\text { D. W as g/plant weeding check }} \times 100$

\section{Determination of oil content of peanut seeds:}

The oil content of peanut seeds was determined according to the methods of A.O.A.C. Washington (1975). The method is based on extraction of fat by using petroleum ether through soxhlet apparatus. To determine weights of seeds before and after extraction represented oil content -two seed samples of each plot, 2 g. of each sample were grounded with blender to fine powder. The grounded sample was put into the set tube of soxhlet apparatus and filled with petroleum ether (bp $<70^{\circ} \mathrm{C}$ ) and shaking frequently. The soxhlet was fitted on water bath for about 10 hours until upper liquid (70 $\left.80^{\circ} \mathrm{C}\right)$. When petroleum ether extract became particularly clear, more petroleum ether was added to set tube during extractions possesses. The sample accurately weight and the percent oil were calculated.

\section{Determination of protein content of peanut seeds:}

The protein content of peanut seeds was determined according to the methods of A.O.A.C. Washington (1975). The method is depending on digestion of protein of peanut seeds to nitrogen by using kjeldahl apparatus. Two seed samples (fine powder) of each plot, each $2 \mathrm{~g}$, were putted in digestion flask of kjeldahl. After digestion and titration possesses were achieved the protein content of peanut seeds was calculated by multiplying nitrogen percentage of sample by 6.25 .

The obtained data were computed and statistically analyzed as complete randomized blocks designed by the aid Mstat program to determine the significance of the differences among the percentages reduction of the treatments.

\section{RESULTS AND DISCUSSION}

\section{Chlorophyll (a, b and total) in peanut plants:}

Data presented in Tables (1 and 2) showed the effect of chemical control of weeds using the herbicides, pendimethalin, and oxyfluorfen, (as pre) and fluazifop - P - butyl and clethodim (as post emergence herbicides) on chlorophyll ( $\mathrm{a}, \mathrm{b}$ and total) in peanut plants, during 2004 and 2005 seasons. The results of the 12 experiments clearly showed that all chemical treatments induced an increase in the formations of chlorophyll ( $a$ and b), either the herbicides were applied as pre or post emergence. The highest increase in chlorophyll content was achieved with the treatment of clethodim at half rate $+1500 \mathrm{ml}$ oil throughout the two experimental seasons. The total chlorophyll resulted from the former treatments were 8.05 and $7.48 \mathrm{mg} / \mathrm{g}$ (D.Wt) during 2004 and 2005 seasons respectively. The increasing percentages were $174.7 \%$ during 2004, and $187.7 \%$ during 2005 seasons.

The lowest increase in total content of chlorophyll was caused by the treatment of clethodim at half rate without oil during 2004 and 2005 seasons. The total chlorophyll values were 4.5 and $4.01 \mathrm{mg} / \mathrm{g}$ (D.Wt) during 2004, and 2005 seasons respectively. The increasing percentages were $53.6 \%$ and $55.0 \%$ during 2004 and 2005 seasons, respectively.

Such effect may give an advantage for peanut plant to grow without any competition from weeds, which leads to formation of the highest content of chlorophyll comparing with untreated plants.

\section{Dry weight of peanut plants:}

Data presented in Tables (3 and 4) showed the effect of the tested herbicides on dry weight of peanut plants during 2004 and 2005 seasons. The results showed that all the treatments resulted in increase of the dry weight of peanut plants. The highest effect was more pronounced from the post - emergence treatment especially for the half rate of clethodim plus $1500 \mathrm{ml}$ of mineral oil.

The dry weights of peanut plants ( $\mathrm{g} /$ plant), were $12.5,35.25$ and 57.72 in 2004 season and 12.5, 45.81 and 60.79 in 2005 season after 45,75 and 105 days intervals after sowing, respectively. 
Table (1): Effect of certain herbicides on chlorophyll (a and b) in peanut plants during 2004 and 2005 seasons

\begin{tabular}{|c|c|c|c|c|c|}
\hline \multirow{2}{*}{ Treatments } & \multirow{2}{*}{$\begin{array}{l}\text { Rate g } \\
\text { (a.i)/fed }\end{array}$} & \multicolumn{2}{|c|}{2004 season } & \multicolumn{2}{|c|}{2005 season } \\
\hline & & chlorophyll a* & chlorophyll b* & chlorophyll a* & chlorophyll b* \\
\hline \multicolumn{6}{|c|}{ Pre-emergence herbicides } \\
\hline Pendimethalin 12\% EC & $850.0 \mathrm{~g}$ & 3.06 & 4.0 & 3.26 & 3.60 \\
\hline Pendimethalin $12 \%$ EC & $425.0 \mathrm{~g}$ & 2.40 & 3.56 & 2.18 & 2.56 \\
\hline Oxyfluorfen $12 \%$ EC & $180.0 \mathrm{~g}$ & 2.96 & 3.64 & 3.59 & 2.99 \\
\hline Oxyfluorfen $12 \%$ EC & $90.0 \mathrm{~g}$ & 2.67 & 2.56 & 2.53 & 2.98 \\
\hline \multicolumn{6}{|c|}{ post - emergence herbicides } \\
\hline Fluazifop-p- butyl & $187.5 \mathrm{~g}$ & 3.02 & 4.41 & 3.20 & 3.07 \\
\hline Fluazifop-p-butyl & $93.75 \mathrm{~g}$ & 2.84 & 2.23 & 1.86 & 2.18 \\
\hline $\begin{array}{l}\text { Fluazifop-p-butyl+ } \\
\text { (KZ oil) }\end{array}$ & $\begin{array}{r}93.75 \mathrm{~g} \\
+1000 \mathrm{ml}\end{array}$ & 3.06 & 3.37 & 2.35 & 2.91 \\
\hline $\begin{array}{l}\text { Fluazifop-p-butyl }+ \\
\text { (KZ oil) }\end{array}$ & $\begin{array}{r}93.75 \mathrm{~g} \\
+1500 \mathrm{ml}\end{array}$ & 3.05 & 4.02 & 2.67 & 3.22 \\
\hline Clethodim & $125.0 \mathrm{~g}$ & 2.75 & 3.75 & 2.83 & 3.33 \\
\hline Clethodim & $62.5 \mathrm{~g}$ & 2.23 & 2.2 & 2.08 & 2.19 \\
\hline Clethodim+(KZ oil) & $\begin{array}{c}62.5 \mathrm{~g}+1000 \\
\mathrm{ml}\end{array}$ & 2.62 & 3.57 & 2.48 & 3.36 \\
\hline Clethodim+(KZ oil) & $\begin{array}{c}62.5 \mathrm{~g}+1500 \\
\mathrm{ml}\end{array}$ & 3.16 & 4.89 & 3.43 & 4.05 \\
\hline Weedy check & & 1.53 & 1.40 & 1.45 & 1.11 \\
\hline
\end{tabular}

Table (2): Percentage increase in total content of chlorophyll in peanut plants during 2004 and 2005 seasons

\begin{tabular}{|c|c|c|c|c|c|}
\hline \multirow{2}{*}{ Treatments } & \multirow{2}{*}{$\begin{array}{l}\text { Rate g } \\
\text { (a.i)/fed }\end{array}$} & \multicolumn{2}{|c|}{ Total chlorophyll * } & \multicolumn{2}{|c|}{$\%$ increasing } \\
\hline & & 2004 & 2005 & 2004 & 2005 \\
\hline \multicolumn{6}{|c|}{ Pre-emergence herbicides } \\
\hline Pendimethalin $12 \%$ EC & 850.0 g. & 7.15 & 5.86 & 144.0 & 125.4 \\
\hline Pendimethalin $12 \%$ EC & $425.0 \mathrm{~g}$ & 5.96 & 4.64 & 103.4 & 78.5 \\
\hline Oxyfluorfen $12 \%$ EC & $180.0 \mathrm{~g}$ & 6.60 & 6.58 & 125.3 & 153.1 \\
\hline Oxyfluorfen $12 \%$ EC & $90.0 \mathrm{~g}$ & 4.73 & 5.51 & 61.4 & 111.9 \\
\hline \multicolumn{6}{|c|}{ Post - emergence herbicides } \\
\hline Fluazifop-p- butyl & $187.5 \mathrm{~g}$ & 8.03 & 6.27 & 174.1 & 141.2 \\
\hline Fluazifop-p-butyl & $93.75 \mathrm{~g}$ & 5.07 & 4.04 & 73.0 & 55.4 \\
\hline Fluazifop-p-butyl+ (KZ oil) & $\begin{array}{c}93.75 \mathrm{~g}+1000 \\
\mathrm{ml}\end{array}$ & 6.43 & 5.26 & 119.5 & 102.3 \\
\hline Fluazifop-p-butyl + (KZ oil) & $\begin{array}{c}93.75 \mathrm{~g}+1500 \\
\mathrm{ml}\end{array}$ & 7.53 & 5.89 & 157.0 & 126.5 \\
\hline Clethodim & $125.0 \mathrm{~g}$ & 6.50 & 6.16 & 121.8 & 136.9 \\
\hline Clethodim & $62.5 \mathrm{~g}$ & 4.50 & 4.01 & 53.6 & 55.0 \\
\hline Clethodim+(KZ oil) & $\begin{array}{c}62.5 \mathrm{~g}+1000 \\
\mathrm{ml}\end{array}$ & 6.19 & 5.84 & 111.3 & 124.6 \\
\hline Clethodim+(KZ oil) & $\begin{array}{c}62.5 \mathrm{~g}+1500 \\
\mathrm{ml}\end{array}$ & 8.05 & 7.48 & 174.7 & 187.7 \\
\hline Weedy check & ----- & 2.93 & 2.66 & 0.00 & 0.00 \\
\hline
\end{tabular}

$* \mathrm{Mg} / \mathrm{g}(\mathrm{D} . \mathrm{Wt})$ 
Table (3): Effect of certain herbicides on dry weight of peanut plants during 2004 season

\begin{tabular}{|c|c|c|c|c|}
\hline \multirow{2}{*}{ Treatments } & \multirow{2}{*}{ Rate g (i.e.) / Fed } & \multicolumn{3}{|c|}{ Dry weight as g / plant } \\
\hline & & 45 days & 75 days & 105 days \\
\hline \multicolumn{5}{|c|}{ Pre-emergence herbicides } \\
\hline Pendimethalin $12 \%$ EC & $850.0 \mathrm{~g}$. & 14.6 & 32.4 & 50.72 \\
\hline Pendimethalin $12 \%$ EC & $425.0 \mathrm{~g}$ & 10.08 & 21.58 & 40.26 \\
\hline Oxyfluorfen $12 \%$ EC & $180.0 \mathrm{~g}$ & 12.50 & 24.58 & 46.22 \\
\hline Oxyfluorfen 12\% EC & $90.0 \mathrm{~g}$ & 8.94 & 20.89 & 41.99 \\
\hline \multicolumn{5}{|c|}{ Post - emergence herbicides } \\
\hline Fluazifop-p- butyl & $187.5 \mathrm{~g}$ & 10.63 & 28.88 & 46.6 \\
\hline Fluazifop-p-butyl & $93.75 \mathrm{~g}$ & 8.51 & 23.40 & 44.54 \\
\hline Fluazifop-p-butyl+ (KZ oil) & $93.75 \mathrm{~g}+1000 \mathrm{ml}$ & 10.18 & 32.40 & 46.4 \\
\hline Fluazifop-p-butyl + (KZ oil) & $93.75 \mathrm{~g}+1500 \mathrm{ml}$ & 11.62 & 35.08 & 51.12 \\
\hline Clethodim & $125.0 \mathrm{~g}$ & 11.16 & 32.84 & 51.05 \\
\hline Clethodim & $62.5 \mathrm{~g}$ & 8.85 & 25.31 & 50.90 \\
\hline Clethodim+(KZ oil) & $62.5 \mathrm{~g}+1000 \mathrm{ml}$ & 10.14 & 33.37 & 55.63 \\
\hline Clethodim+(KZ oil) & $62.5 \mathrm{~g}+1500 \mathrm{ml}$ & 12.5 & 35.25 & 57.72 \\
\hline Weedy check & ---- & 6.80 & 12.712 & 23.73 \\
\hline
\end{tabular}

Table (4): Effect of certain herbicides on dry weight of peanut plants during 2005 season

\begin{tabular}{|c|c|c|c|c|}
\hline \multirow{2}{*}{ Treatments } & \multirow{2}{*}{ Rate g (i.e.) / Fed } & \multicolumn{3}{|c|}{ Dry weight as g / plant } \\
\hline & & 45 days & 75 days & 105 days \\
\hline \multicolumn{5}{|c|}{ Pre-emergence herbicides } \\
\hline Pendimethalin $12 \%$ EC & $850.0 \mathrm{~g}$. & 12.02 & 39.63 & 56.30 \\
\hline Pendimethalin $12 \%$ EC & $425.0 \mathrm{~g}$ & 8.62 & 26.45 & 46.36 \\
\hline Oxyfluorfen $12 \%$ EC & $180.0 \mathrm{~g}$ & 11.87 & 30.71 & 52.61 \\
\hline Oxyfluorfen $12 \%$ EC & $90.0 \mathrm{~g}$ & 8.96 & 27.12 & 45.61 \\
\hline \multicolumn{5}{|c|}{ Post - emergence herbicides } \\
\hline Fluazifop-p- butyl & $187.5 \mathrm{~g}$ & 9.45 & 35.17 & 50.12 \\
\hline Fluazifop-p-butyl & $93.75 \mathrm{~g}$ & 7.94 & 28.88 & 45.53 \\
\hline $\begin{array}{l}\text { Fluazifop-p-butyl+ } \\
\text { (KZ oil) }\end{array}$ & $93.75 \mathrm{~g}+1000 \mathrm{ml}$ & 8.47 & 36.27 & 49.01 \\
\hline $\begin{array}{l}\text { Fluazifop-p-butyl + } \\
\text { (KZ oil) }\end{array}$ & $93.75 \mathrm{~g}+1500 \mathrm{ml}$ & 9.93 & 38.2 & 52.91 \\
\hline Clethodim & $125.0 \mathrm{~g}$ & 9.0 & 37.2 & 63.0 \\
\hline Clethodim & $62.5 \mathrm{~g}$ & 7.52 & 31.17 & 50.06 \\
\hline Clethodim+(KZ oil) & $62.5 \mathrm{~g}+1000 \mathrm{ml}$ & 8.66 & 41.77 & 57.06 \\
\hline Clethodim+(KZ oil) & $62.5 \mathrm{~g}+1500 \mathrm{ml}$ & 12.50 & 45.81 & 60.79 \\
\hline Weedy check & --- & 5.94 & 15.51 & 26.44 \\
\hline
\end{tabular}


Dry weight of pods:

Data presented in Tables (5 and 6) showed the effect of the tested herbicides on dry weight of peanut mature pods, 75 and 105 days after sowing during 2004 and 2005 seasons. The obtained results clearly showed that all treatments induced increases in the dry weight of peanut mature pods. The highest percentage of increase was recorded with the treatment of clethodim at half rate plus $1500 \mathrm{ml}$ of mineral oil, which gave 501 and $541.2 \%$, during 2004 season and became 546.7 and $568.2 \%$ during 2005 season, such increases were obtained after, 75 and 105 days intervals after sowing during 2004 and 2005 seasons, respectively.

Table (5): Effect of certain herbicides on dry weight of peanut mature pods during 2004 and 2005 seasons

\begin{tabular}{|c|c|c|c|c|c|}
\hline \multirow{3}{*}{ Treatments } & \multirow{3}{*}{ Rate g (i.e.) / Fed } & \multicolumn{4}{|c|}{ Dry weight of mature pods as g / plant } \\
\hline & & \multicolumn{2}{|c|}{2004} & \multicolumn{2}{|c|}{2005} \\
\hline & & 75 days & 105 days & 75 days & 105 days \\
\hline \multicolumn{6}{|c|}{ Pre-emergence herbicides } \\
\hline Pendimethalin12\% EC & $850.0 \mathrm{~g}$. & 9.58 & 24.11 & 10.19 & 29.92 \\
\hline Pendimethalin12\% EC & $425.0 \mathrm{~g}$ & 6.07 & 19.92 & 7.46 & 20.94 \\
\hline Oxyfluorfen $12 \%$ EC & $180.0 \mathrm{~g}$ & 12.69 & 29.66 & 13.39 & 36.96 \\
\hline Oxyfluorfen $12 \%$ EC & $90.0 \mathrm{~g}$ & 8.34 & 19.89 & 9.43 & 23.98 \\
\hline \multicolumn{6}{|c|}{ Post-emergence herbicides } \\
\hline Fluazifop-p- butyl & $187.5 \mathrm{~g}$ & 13.15 & 37.46 & 13.59 & 40.65 \\
\hline Fluazifop-p-butyl & $93.75 \mathrm{~g}$ & 6.96 & 20.79 & 7.14 & 27.97 \\
\hline $\begin{array}{l}\text { Fluazifop-p-butyl+ } \\
\text { (KZ oil) }\end{array}$ & $93.75 \mathrm{~g}+1000 \mathrm{ml}$ & 13.12 & 35.29 & 12.33 & 34.0 \\
\hline $\begin{array}{l}\text { Fluazifop-p-butyl + } \\
\text { (KZ oil) }\end{array}$ & $93.75 \mathrm{~g}+1500 \mathrm{ml}$ & 14.07 & 37.62 & 14.77 & 36.76 \\
\hline Clethodim & $125.0 \mathrm{~g}$ & 14.50 & 36.68 & 14.24 & 39.86 \\
\hline Clethodim & $62.5 \mathrm{~g}$ & 9.63 & 25.30 & 9.74 & 26.47 \\
\hline Clethodim+(KZ oil) & $62.5 \mathrm{~g}+1000 \mathrm{ml}$ & 13.74 & 31.91 & 12.17 & 38.65 \\
\hline Clethodim+(KZ oil) & $62.5 \mathrm{~g}+1500 \mathrm{ml}$ & 15.75 & 37.98 & 17.72 & 40.96 \\
\hline Weedy check & --- & 2.62 & 5.19 & 2.74 & 6.13 \\
\hline
\end{tabular}

Table (6): Effect of certain herbicides on increasing percentage of dray weight of peanut mature pods during 2004 and 2005 seasons

\begin{tabular}{|c|c|c|c|c|c|}
\hline \multirow{3}{*}{ Treatments } & \multirow{3}{*}{ Rate g (i.e.) / Fed } & \multicolumn{4}{|c|}{$\%$ increasing dry weight of mature pods as g / plant } \\
\hline & & \multicolumn{2}{|c|}{2004} & \multicolumn{2}{|c|}{2005} \\
\hline & & 75 days & 105 days & 75 days & 105 days \\
\hline \multicolumn{6}{|l|}{ Pre-emergence herbicides } \\
\hline Pendimethalin 12\% EC & $850.0 \mathrm{~g}$. & 265.6 & 364.5 & 271.9 & 388.1 \\
\hline Pendimethalin $12 \%$ EC & $425.0 \mathrm{~g}$ & 131.7 & 226.0 & 172.3 & 241.6 \\
\hline Oxyfluorfen $12 \%$ EC & $180.0 \mathrm{~g}$ & 384.4 & 471.5 & 388.7 & 498.5 \\
\hline Oxyfluorfen $12 \%$ EC & $90.0 \mathrm{~g}$ & 218.3 & 283.2 & 244.2 & 291.2 \\
\hline \multicolumn{6}{|c|}{ Post - emergence herbicides } \\
\hline Fluazifop-p- butyl & $187.5 \mathrm{~g}$ & 401.9 & 521.8 & 395.9 & 563.1 \\
\hline Fluazifop-p-butyl & $93.75 \mathrm{~g}$ & 165.6 & 300.6 & 160.6 & 365.3 \\
\hline $\begin{array}{l}\text { Fluazifop-p-butyl+ } \\
\text { (KZ oil) }\end{array}$ & $93.75 \mathrm{~g}+1000 \mathrm{ml}$ & 400.8 & 510.9 & 350.0 & 454.6 \\
\hline $\begin{array}{l}\text { Fluazifop-p-butyl + } \\
\text { (KZ oil) }\end{array}$ & $93.75 \mathrm{~g}+1500 \mathrm{ml}$ & 437.0 & 524.1 & 439.1 & 499.7 \\
\hline Clethodim & $125.0 \mathrm{~g}$ & 453.4 & 606.7 & 419.7 & 550.2 \\
\hline Clethodim & $62.5 \mathrm{~g}$ & 267.6 & 387.5 & 255.5 & 331.8 \\
\hline Clethodim $+(\mathrm{KZ}$ oil $)$ & $62.5 \mathrm{~g}+1000 \mathrm{ml}$ & 424.4 & 514.8 & 344.2 & 550.5 \\
\hline Clethodim+(KZ oil) & $62.5 \mathrm{~g}+1500 \mathrm{ml}$ & 501.1 & 541.2 & 546.7 & 568.2 \\
\hline Weedy check & -- & --- & --- & --- & --- \\
\hline
\end{tabular}


Effect of the tested herbicides is in a shadow to the effect these herbicides on dry weight of peanut plants. The highest increase in mature pods with the post - emergence treatments are in correlation to the highest increase in dry weight of plant as well as for clethodim at half rate plus $1500 \mathrm{ml}$ of mineral oil, with 501.1 and $541.2 \%$ increases in weights of dry peanut mature pods, during 2004 season and became 547.7and $568.2 \%$, after 75 and 105 days after sowing during 2005 season.

These results are in the same trend to those reported earlier (Bollich et al., 1988; Hassan and Metwally, 2001; Kumar et al., 2003).
Oil and protein content of peanut seeds:

Data in Table (7) showed the effect of the tested herbicides on the crude protein and oil content in peanut seeds during 2004 and 2005 seasons. The statistical analyses revealed that no significant effect was found between the treated and untreated plants.

These results were in agreement with those obtained by Ibrahim (1995) who indicated that pendimethalin at $850 \mathrm{~g} /$ fed had no effect on oil and crude protein content of peanut seed compared to untreated plants.

Table (7): Effect of certain herbicides on oil and crude protein content during 2004 and 2005 seasons

\begin{tabular}{|c|c|c|c|c|c|}
\hline \multirow{2}{*}{ Treatments } & \multirow{2}{*}{ Rate g (i.e.) / Fed } & \multicolumn{2}{|c|}{2004} & \multicolumn{2}{|l|}{2005} \\
\hline & & Oil \% & Protein \% & Oil \% & Protein \% \\
\hline \multicolumn{6}{|c|}{ Pre-emergence herbicides } \\
\hline Pendimethalin $12 \%$ EC & $850.0 \mathrm{~g}$. & 53.21 & 15.57 & 52.57 & 16.37 \\
\hline Pendimethalin $12 \%$ EC & $425.0 \mathrm{~g}$ & 52.49 & 15.19 & 53.31 & 16.00 \\
\hline Oxyfluorfen $12 \%$ EC & $180.0 \mathrm{~g}$ & 52.4 & 13.44 & 52.69 & 16.36 \\
\hline Oxyfluorfen $12 \%$ EC & $90.0 \mathrm{~g}$ & 53.12 & 14.91 & 52.96 & 15.13 \\
\hline \multicolumn{6}{|c|}{ Post - emergence herbicides } \\
\hline Fluazifop-p- butyl & $187.5 \mathrm{~g}$ & 54.26 & 16.04 & 51.69 & 17.15 \\
\hline Fluazifop-p-butyl & $93.75 \mathrm{~g}$ & 53.0 & 15.31 & 52.82 & 14.58 \\
\hline $\begin{array}{l}\text { Fluazifop-p-butyl+ } \\
\text { (KZ oil) }\end{array}$ & $93.75 \mathrm{~g}+1000 \mathrm{ml}$ & 52.94 & 15.83 & 53.49 & 14.80 \\
\hline $\begin{array}{l}\text { Fluazifop-p-butyl + } \\
\text { (KZ oil) }\end{array}$ & $93.75 \mathrm{~g}+1500 \mathrm{ml}$ & 54.45 & 16.20 & 53.05 & 15.58 \\
\hline Clethodim & $125.0 \mathrm{~g}$ & 52.94 & 15.83 & 53.49 & 14.8 \\
\hline Clethodim & $62.5 \mathrm{~g}$ & 51.71 & 16.72 & 53.33 & 17.97 \\
\hline Clethodim+(KZ oil $)$ & $62.5 \mathrm{~g}+1000 \mathrm{ml}$ & 53.99 & 15.83 & 54.00 & 116.02 \\
\hline Clethodim $+(\mathrm{KZ}$ oil $)$ & $62.5 \mathrm{~g}+1500 \mathrm{ml}$ & 52.97 & 15.73 & 53.08 & 15.70 \\
\hline Weedy check & --- & 52.29 & 15.51 & 53.27 & 15.92 \\
\hline LSD 5\% & & 52.09 & 15.13 & 53.9 & 14.96 \\
\hline
\end{tabular}

\section{REFERENCES}

A.O.A.C. (1975). Washington (Association of Official Analytical Chemists). Washington, D. C. (1975). Official and tentative methods of analysis of the Association of Official Agriculture Chemists, 158: 8.

Barrol, A. C. (1989). Efficacy of post - emergence herbicides for control of grass weeds in soybeans crops. Comunicado Tecnico Empresa Goiana de Pesquisa Agropecuaris, 18: 8.

Bollich, P. K., E. P. Dunagan, L. M. Kitchen and V. Taylor (1988). The influence of trifluralin and of pendimethalin on nodulation, $\mathrm{N} 2(\mathrm{C} 2 \mathrm{H} 2)$ fixation and yield of field grown soybean (Glycine max). Weeds Sci., 36: 1519.

Colvin, D. L., G. R. Wehtje, M. Patterson and R. H. Walker (1985). Weed management in minimum - tillage peanut (Arachis hypoagea L.) as influenced by cultivar, row spacing mid herbicides. Weeds Sci., 33: 233-237.

Deer, J. F., T. J. Monaco and T. J. Sheets (1985). Response of three annual grasses to fluazifop. Weeds Sci., 33: 693 - 697.

Ennis, B. G. and R. A. Ashley (1988). Effectiveness of BAS- 9052-OH, diclofop and CGA-82725 applied at various stage of growth of crabgrass. Proc. Northeast Weeds Sci., 36: 151-153. 
Fadl, M. S. and Sari El-Deen (1978). Effect of N6benzyl adeneine on photosynthetic pigments and total soluble sugars of olive seedling grown under saline condition in Urtica dioica L. plant by increasing cytokinin import into Shoot. Egyptian J. Hort., 6: 169183.

Fletcher, W. J. and R. C. Kirkwood (1982). Herbicides and plant regulators. 24-25. Granada Publ., London.

Glemmestad, E. (1985). Control of couchgrass. NorskLandbruk, 104: 22-54.

Grichar W. J. and T. E. Boswell (1986). Post emergence grass control in peanut (Arachis hypoagea L). Weed Sci., 34: 587-590.

Hassan, A. A. and G. M. Metwally (2001). Growth and yield components of groundnut plants as affected by some herbicides treatments. Bull NRC, Egypt, 26(4): 493-495.

Ibrahim, M. F. (1995). Effect of some herbicides on groundnut in newly reclaimed soils. M.Sc. Thesis, Fac. of Agric., Al-Azhar Univ.
Kudsk, P. (1984). A method for determining the influence of additives in herbicides performance. 1-Danske plante vaernskonference, Ukrudt., 178-195.

Kumar, Y., M. S. Shaktwat, S. Singh and O. P. Gill (2003). Integrated weed management in irrigated groundnut (Arachis hypoagea L.). Indian, J. of Agron., 48: 117-119.

Rogers, N. K., L. R. Oliver and R. T. Talbert (1980). Weeds Management in peanut (Arachis hypoagea L) with Imazelhapyr and Metolachor Richburg. Weed technol., 9: 807-812.

Silva, J. F., L. M. D. Costa and C. M. D. Silva (1983). Effect of weed control with herbicides on bioduction and physiological quality of groundnut (Arachis hypoagea L) seeds. Planta Daninha, 6: 115-122.

Wettstein, D. V. (1957). Chlorophyll - lataleunder submikroskroskopische for meuechsd der plastiden. Expr. Cell. Res., 12: 427-433.

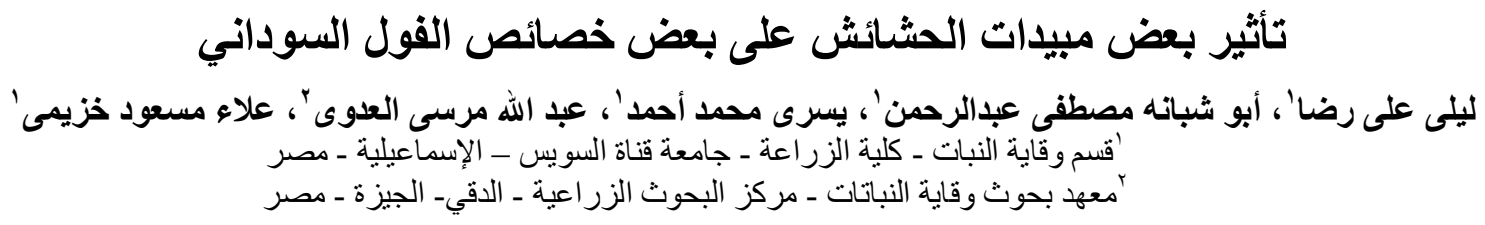

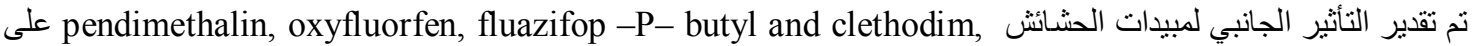

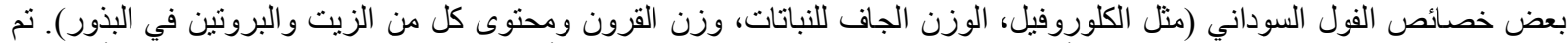

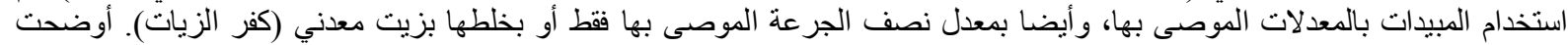

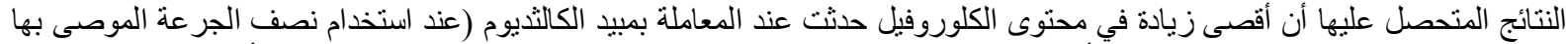

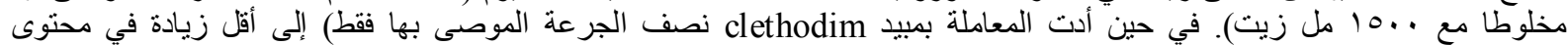

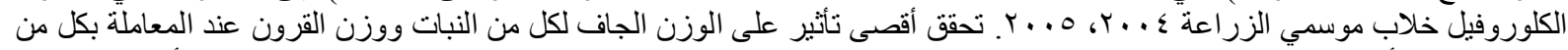

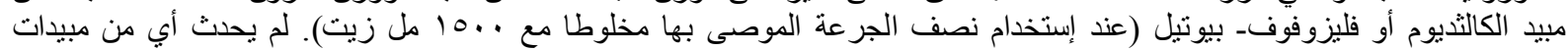
الحثائش المختبرة أي تأثير على محتوى أي من محتوى الزيت أو محتوى البروتين في نباتات الفول السون السوداني. 